\title{
Effect of Dietary Supplementation of Inulin on Growth Performance, Digestion Enzyme Activities and Antioxidant Status of Rainbow Trout (Oncorhynchus mykiss)
}

\author{
Arzu Özlüer Hunt ${ }^{1, a, *}$, Mükerrem Çetinkaya ${ }^{1, b}$, Ferbal Özkan Yılmaz ${ }^{2, c}$, Metin Yıldırım $^{3, d}$, \\ Mehmet Berköz ${ }^{4, e}$, Serap Yalın ${ }^{3, f}$ \\ ${ }^{I}$ Department of Aquaculture, Faculty of Fisheries, Mersin University, 33160 Mersin, Turkey \\ ${ }^{2}$ Department of Basic Sciences, Faculty of Fisheries, Mersin University, 33160 Mersin, Turkey \\ ${ }^{3}$ Department of Biochemistry, Faculty of Pharmacy, Mersin University, 33160 Mersin, Turkey \\ ${ }^{4}$ Department of Pharmaceutical Technology, Faculty of Pharmacy, Yuzuncu Yll University, 65090 Van, Turkey \\ *Corresponding author
}

A R T I C L E I N F O
Research Article
Received : 03/04/2019
Accepted : 11/07/2019

Keywords:

Oncorhynchus mykiss

Inulin

Growth

Enzyme activity

Prebiotic

\begin{abstract}
A B S T R A C T
The present study investigated the effects of the prebiotic inulin on the growth parameters, digestive enzyme activities and antioxidant status of rainbow trout (Oncorhynchus mykiss). After acclimation, fish ( $34 \pm 0.22 \mathrm{~g} ; \mathrm{n}=135)$ were assigned into 9 tanks ( 15 fish per tank) and triplicate groups were fed a control diet (G-0) or diets containing $1 \%$ (G-1) or $2 \%$ (G-2) inulin. At the end of the trial (8 weeks), growth factors (final weight, weight gain, specific growth rate (SGR), food conversion ratio (FCR), protein efficiency ratio (PER), Economic conversion ratio (ECR), digestive enzyme activities (pepsin, trypsin, amylase and lipase) and antioxidant status superoxide dismutase (SOD), catalase (CAT) and malondialdehyde (MDA) level of liver tissue were assessed. At the end of the study highest survival rate was observed in the fish fed with $1 \%$ G-1 inulin group. Similarly, digestive enzyme activities were significantly higher dietary G-1 group. Subsequently, elevated growth performance (final weight, SGR and FCR) was observed in trout fed with $1 \%$ compared to the control group. The effect of the dietary inulin on digestion was partly observed by assaying the activity of pepsin, intestinal amylase, trypsin and lipase. Apart from pepsin activity, results indicated that dietary supplementation of inulin is beneficial and may also have differential effects upon digestive enzyme activities. Antioxidant enzyme activity of SOD and CAT in liver tissue was generally higher in the supplemented inulin diets than in the control and significantly higher in the $1 \%$ inulin group. A significant decrease in MDA level of tissue was observed in all inulin supplemented groups when compared to the control group. These results indicate that inulin be considered as a beneficial dietary supplement for growth performance, digestive enzyme activities and antioxidant status of rainbow trout.
\end{abstract}

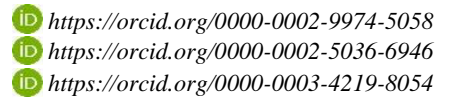

(iD) https://orcid.org/0000-0002-9974-5058

(iD) https://orcid.org/0000-0003-4219-8054

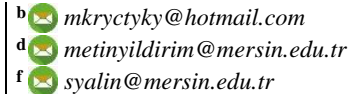

(iD) https://orcid.org/0000-0003-1744-9691

(iD) http://orcid.org/0000-0002-1286-2172

(9) (1) () This work is licensed under Creative Commons Attribution 4.0 International License

\section{Introduction}

World aquaculture has grown extremely through the last years becoming the fastest growing food-producing sector in the world (Denav et al., 2009). Throughout the 2005-2014 period, fish culture production grew at $5.8 \%$ per year (FAO, 2016). However, aquaculture intensification requires high stocking densities and routine handling, subjecting aquatic species to several stress conditions, which can negatively affect the health and growth (Shrimpton et al., 2001). Thus disease outbreaks were recently recognized as the major restriction to aquaculture production with resulting adverse effects on the industry's economic development. Therefore, conventional approaches were used to control fish diseases, such as antimicrobial agents and vaccination, however, they have had limited success in the prevention and/or treatment of aquatic diseases (Yunxia et al., 2001). In addition to their public health hazards the chemotherapeutic agents exerted ecological threat; because they increase the selective pressure on the microbial world thus encourage the emergence of bacterial resistance (Flores et al., 2003). Therefore, looking for less harmful methods and more environmentally-friendly usages become of superior importance. Demand for environment friendly aquaculture, 
and the use of dietary supplements like probiotic, prebiotic and symbiotic as some alternatives of antibiotic increased (Merrifield et al., 2010) and these dietary supplements have been demonstrated to show beneficial effects on growth performance, survival and disease resistance of fish and shellfish species (Ringø et al., 2010).

Prebiotics are nondigestible food ingredients that beneficially affect the host by selectively stimulating the growth and/or activity of one or a limited number of bacteria in the colon. Intake of prebiotics could significantly modulate the colonic microbiota by increasing the number of specific bacteria and thus changing the composition of the microbiota (Gibson and Roberfroid, 1995). Prebiotics have been found to have positive effects in humans (Causey et al., 1998), poultry (Patterson and Burkholder, 2003) and swine (SmirickyTjardes et al., 2003). It was reported that prebiotics can modify the gastrointestinal (GI) tract microbial community, in turn enhance the non-specific immune responses (Bailey et al., 1991); increase fermentation products (Smiricky-Tjardes et al., 2003); improve mineral uptake (Bongers and van den Heuvel, 2003), as well as enhance livestock performance indices (including protein efficiency ratio (PER), feed conversion ratio (FCR), improve disease resistance (Bailey et al., 1991) and provides to protection against oxidative stress (RaultNania et al., 2008). The potential benefits of prebiotics need more detailed examinations in fish also.

Among the prebiotics used in fish culture inulin and fructooligosaccharide (FOS) are the most well-established ones (Verdonk et al., 2005; Soleimani et al., 2012). Inulin (a heterogeneous blend of fructose polymers) is a naturally occurring fructooligossacharide (FOS). They are produced by many types of plants and belong to a class of carbohydrates known as fructans, so that they are mainly comprised of fructose units and, typically, have a terminal glucose. It is extracted from the chicory root (Cichorium intybus) plants and belongs to a class of carbohydrates known as fructans (Goodwin and Mercer, 1983). Fructans are non-digestible oligosaccharides as the $\beta$-(2-1) linkage of the fructans cannot be hydrolysed by pancreatic or brush border digestive enzymes in the proximal intestinal tract of human and domestic animals (Pool-Zobel et al., 2002). It is fermented in the large intestine or colon by beneficial bifidobacteria and other lactic acid-producing bacteria, increasing the irrelative populations (Tzortzis et al., 2005), while selectively arresting the growth of pathogenic microorganisms (Flickinger et al., 2003), the regulation of intestinal epithelial cell growth and increase (Roberfroid, 2005); These potential benefits of inulin have not been thoroughly investigated in fish.

Antioxidant enzymes are natural defenses that can be enhanced under stressful situations and used as indicators of oxidative stress (Livingstone, 2001). In vitro and in vivo studies demonstrate the capacity of fish to generate reactive oxygen species (ROS) by xenobiotics, physical conditions, and/or diet. Defense systems that may inhibit ROS formation include antioxidant enzymes such as superoxide dismutase (SOD), catalase (CAT). Malondialdehyde (MDA) is the main oxidation product of peroxidized polyunsaturated fatty acids and raised MDA level is an important index of lipid peroxidation (LPO) (Elia et al., 2002). Prebiotics such as inulin -type fructans become more popular as food ingredients in lately. Evidence is accumulating that carbohydrates and carbohydrate-containing biomolecules can be considered true antioxidants, capable of scavenging ROS (Stoyanova et al., 2011).

Dietary supplementation of FOS or inulin has been shown to enhance growth rates and/or the survival of aquatic animals such as hybrid tilapia, Oreochromis niloticus (Ibrahem et al., 2010), Siberian sturgeon, Acipenser baeri (Mahious and Ollever, 2005), African catfish, Clarias gariepinus (Mahious and Ollever, 2005), turbot, Psetta maxima larvae (Mahious et al., 2006), Atlantic salmon, Salmo salar (Grisdale-Helland et al., 2008), red drum, Sciaenops ocellatus (Zhou et al., 2010), Beluga, Huso huso (Hoseinifar et al., 2011), Caspian roach, Rutilus rutilus fry (Soleimani et al., 2012), rainbow trout, Oncorhynchus mykiss (Ortiz et al., 2013) and sturgeon, Acipenser stellatus (Akrami et al., 2013).

To date, numerous studies have confirmed the benefits of prebiotics on the fish growth. However, there is very little information concerning the effects of prebiotics in fish digestion and antioxidant enzyme activities. Thus, the present study aims to determine the effects of inulin on the digestive enzymes and antioxidant status of rainbow trout (O. mykiss), a very important fish species in the world while showed while the potential use of the inulin as fish growth and enzyme activity discussed.

\section{Materials and Methods}

\section{Diet Formulation and Preparation}

Three balanced isonitrogenous and isoenergetic diets were formulated to contain commercial prebiotic inulin derived from chicory root (Sigma Aldrich, USA/ Lot\# SLBH0425V), the main protein sources of anchovy meal and corn gluten in the control group not contain inulin diet with different ratio inulin $1 \%$, and $2 \%$ on a dry matter basis (Table 1). In all diets in the experiment fish oil was the main oil source and dextrin was the carbohydrate source (Table 1).

\section{Experimental Systems and Animals}

The experiment was conducted using 9 plastic 200-1 tanks. The system was installed in an environmentallycontrolled laboratory at the fish culture unit in the Faculty of Fisheries, Mersin University, where air temperature is maintained at $12-13^{\circ} \mathrm{C}$, and the photoperiod at $12 \mathrm{~L}: 12 \mathrm{D}$. Water depth in the tanks was kept at $50 \mathrm{~cm}$ throughout the experiment by adding fresh water continuously from a reservoir tank following daily siphoning of uneaten feed, and feces. All tanks were thoroughly cleaned every 2 weeks after individual fish weight increments were recorded. Dissolved oxygen was measured every other day using YSI model 58 oxygen meters and kept at, or above, $6 \mathrm{mg} / \mathrm{L}$ throughout the experiment (Yellow Springs Instrument Company, Yellow Springs, $\mathrm{OH}) . \mathrm{pH}$ was monitored twice weekly with an electronic $\mathrm{pH}$ meter $(\mathrm{pH}$ pen. Fisher Scientific, Cincinnati, $\mathrm{OH}$ ). Total $\mathrm{NO}_{3}$ levels were monitored once a week using a Merck-Spectroquant ${ }^{\circledR}$ Nova 60A. Water temperature was recorded daily at 13:00 $\mathrm{h}$ using a mercury thermometer suspended at $25-\mathrm{cm}$ depth. Average water quality parameters were temperature $12 \pm$ $0.3^{\circ} \mathrm{C}$, dissolved oxygen $6.2 \pm 0.07 \mathrm{mg} / \mathrm{L}, \mathrm{pH} 7.9 \pm 0.65$, $\mathrm{NO}_{3} 0.7 \pm 0.1 \mathrm{mg} / \mathrm{L}$. 
Table 1 Formulation $\left(\mathrm{g} \mathrm{kg}^{-1}\right.$ diet) and chemical composition of the experimental diets

\begin{tabular}{|c|c|c|c|}
\hline & G0 & G1 & $\mathrm{G} 2$ \\
\hline Fish meal $^{1}$ & 500.00 & 500.00 & 500.00 \\
\hline Fish oil $^{1}$ & 100.00 & 100.00 & 100.00 \\
\hline Corn gluten meal $^{2}$ & 230.00 & 220.00 & 210.00 \\
\hline Dextrin & 100.00 & 100.00 & 100.00 \\
\hline Vitamin ${ }^{3}$ & 20.00 & 20.00 & 20.00 \\
\hline Mineral $^{3}$ & 20.00 & 20.00 & 20.00 \\
\hline Binder (CMC) & 30.00 & 30.00 & 30.00 \\
\hline Inulin & 0.00 & 10.00 & 20.00 \\
\hline \multicolumn{4}{|c|}{ Feed composition $(\mathrm{g} / \mathrm{kg}$ ) } \\
\hline Dry matter & 947.95 & 948.07 & 948.19 \\
\hline Crude protein & 473.84 & 467.63 & 461.42 \\
\hline Crude lipid & 206.58 & 205.70 & 204.81 \\
\hline Crude ash & 119.92 & 119.59 & 119.26 \\
\hline $\mathrm{NFE}^{4}$ & 147.608 & 155.15 & 162.70 \\
\hline Others & 52.054 & 51.93 & 51.81 \\
\hline Gross energy $(\mathrm{kJ} / \mathrm{g})^{5}$ & 18.5 & 18.41 & 18.38 \\
\hline $\mathrm{P}: \mathrm{E}$ & 25.69 & 25.40 & 25.11 \\
\hline \multicolumn{4}{|c|}{ Calculated TAA profile $(\mathrm{g} / \mathrm{kg})$} \\
\hline Arginine & 15.54 & 15.42 & 15.29 \\
\hline Histidine & 7.16 & 7.08 & 7.00 \\
\hline Isoleucine & 14.05 & 13.89 & 13.73 \\
\hline Leucine & 30.91 & 30.28 & 29.66 \\
\hline Lysine & 18.15 & 18.08 & 18.02 \\
\hline Methionine & 8.87 & 8.77 & 8.67 \\
\hline Cystine & 3.69 & 3.61 & 3.54 \\
\hline Phenylalanine & 14.79 & 14.55 & 14.30 \\
\hline Tyrosine & 12.10 & 11.90 & 11.69 \\
\hline Threonine & 12.23 & 12.10 & 11.97 \\
\hline Tryptophan & 3.08 & 3.05 & 3.03 \\
\hline Valine & 15.92 & 15.73 & 15,53 \\
\hline
\end{tabular}

${ }^{1}$ Anchovy fish meal and oil. SIBAL Black Sea Feed Inc., Sinop, Turkey, ${ }^{2}$ SUNAR Inc., Adana, Turkey, ${ }^{3}$ Vitamin and mineral premix added minimum to NRC recommendations, SIBAL Black Sea Feed Inc., Sinop, Turkey (NRC 1993), ${ }^{4}$ Nitrogen-Free Extract: Calculated as the remain of crude protein+crude lipid+ash, ${ }^{5}$ Calculated based on standard physiological fuel values: $19 \mathrm{~kJ} / \mathrm{g}$ for protein, $36 \mathrm{~kJ} / \mathrm{g}$ for lipid and $15 \mathrm{~kJ} / \mathrm{g}$ for carbohydrate (Smith, 1989)

A total of 400 rainbow trout, average initial body weight of $35 \mathrm{~g}$, were obtained from a local trout farm. The trout were acclimated to laboratory conditions for 2 weeks in two 500-1 fiberglass tanks and fed a commercial diet (Crude protein: $48 \%$, crude lipid: $22 \%$, BioAqua Feedİzmir/Turkey) at a level of 3\% of body weight. Following the acclimatization period, 135 fish were individually weighed and randomly distributed ( $15 \mathrm{fish} /$ per tank) where they were acclimated to the experimental system for 2 days without feed. Each of the 3 treatments was replicated 3 times. All fish from all groups were fed twice daily (8:009:00 am and 16:00-17:00 pm) throughout experiment. The uneaten feed and feces were siphoned out 30 minutes after feeding and half of the water in the system was exchanged daily throughout the experiment to maintain water quality.

\section{Growth Performance and Biometric Parameters}

In order to analyze the growth indices of the rainbow trout, all fishes from each tank were measured once every 15 days during the 60-day experiment, at least $12 \mathrm{~h}$ after the last feeding. The fish were weighed individually by a digital scale (bearing: $0.01 \mathrm{mg}$ ) after they had been anesthetized. Based on the results of the biometry, the daily ration of the fish in the supplemented groups and in the control one was determined. At the end of the feeding trial, body weight increase (BWI), percent body weight increase
(PBWI), specific growth rate (SGR), feed conversion ratio (FCR), protein efficiency ratio (PER) and survival rate were calculated according to the following formulas (Akrami et al., 2013):

$$
\begin{array}{ll}
\text { BWI } & =\mathrm{Wt} \_\mathrm{W} 0 \\
\text { PBWI } & =(\mathrm{Wt}-\mathrm{W} 0) \times 100 / \mathrm{W} 0 \\
\text { SGR } & =(\text { LnWt- LnW0 }) \times 100 / \mathrm{t} \\
\text { FCR } & =\text { Dry fed in } \mathrm{g} / \text { wet weight gain in } \mathrm{g} \\
\text { PER } & =\text { Wet WG }(\mathrm{g})-\text { protein intake }(\mathrm{g})
\end{array}
$$$$
\text { Survival rate }=(\mathrm{Nt} / \mathrm{N} 0) / 100
$$

Here Wt and W0 are final and initial body weights (g) respectively, $t$ is duration of experimental days, N0 is the initial number of fish and $\mathrm{Nt}$ is the final number of fish.

\section{Economic Profit Analysis}

Taking into account feed price, the cost of feed required to produce $1 \mathrm{~kg}$ of biomass was also calculated. The parameters of economic conversion ratio (ECR) and Economic Profit Index (EPI) were calculated according to Martinez-Llorens et al. (2007); ECR (US. $\$ / \mathrm{kg}$ ) = Feed cost (US.\$ $/ \mathrm{kg}$ ) x Feed conversion ratio $(\mathrm{kg}$ diet $/ \mathrm{kg}$ fish), The Economic Profit Index [EPI (US\$ /fish) = final weight $(\mathrm{kg} /$ fish) $x$ fish sale price (US\$ $/ \mathrm{kg}$ )-ECR (US\$ $/ \mathrm{kg}$ ) $\times$ weight increase $(\mathrm{kg})$ ]. Rainbow trout sale price used in the equation was US\$2.17 per $\mathrm{kg}$. 
Sampling and Biochemical Analysis

At the end of the study, 27 fish (3 fish per tank, 9 fish per treatment) were randomly chosen from each treatment. Fish were dissected and their tissues were used in biochemical analyzes.

Fish fillets were proximate analyzed for: moisture, by heating at $60^{\circ} \mathrm{C}$ to constant weight; protein, by estimating the Kjeldahl nitrogen $(\times 6.25)$ in an automated distillation unit; lipid, by chloroform/methanol extraction; and ash, by incinerating in a muffle furnace at $550^{\circ} \mathrm{C}$ for $18 \mathrm{~h},(\mathrm{AOAC}$, 1990).

In order to study the effect of inulin on digestive enzyme activity, crude enzymatic extracts were prepared (Ding et al., 2004). A crude mixture of intestine was obtained by dissection at $4^{\circ} \mathrm{C}$, and rinsed with cold $\mathrm{NaCl}$ (Sigma) solution $(0.8 \%)$. Then the total intestinal content was homogenized at $4^{\circ} \mathrm{C}$ in $50 \mathrm{~mm}$ phosphate buffer $(\mathrm{pH}$ 7.4) in a homogenizer. The homogenate was centrifuged at $10000 \mathrm{rpm}$ for $10 \mathrm{~min}$ at $+4^{\circ} \mathrm{C}$. The supernatant was recovered and kept at $-80^{\circ} \mathrm{C}$.

Pepsin (E.C.3.4.23.1) activity was assayed using 2\% hemoglobin from bovine blood in $\mathrm{HCl}$ as a substrate (Worthington 1993). Tissue homogenate $(1 \mathrm{ml})$ in $\mathrm{HCl}$ with $5 \mathrm{ml}$ of substrate was incubated at $37^{\circ} \mathrm{C}$ for $10 \mathrm{~min}$. The reaction was terminated using $5 \%$ trichloroacetic acid (TCA) (Sigma) and left to incubate for $5 \mathrm{~min}$. The mixture was then filtered. Absorbance was measured at $280 \mathrm{~nm}$. One unit renders TCA soluble absorption of 0.001 at 280 $\mathrm{nm}$ per min. at $37^{\circ} \mathrm{C}$ from a denatured hemoglobin substrate.

Trypsin (E.C.3.4.21.4) activity was measured (Erlanger et al., 1961) and the measurements modified using benzoyl-DL-arginin-p-nitroanilide (BAPNA, Sigma) as a substrate (Benjakul et al., 2000). A sample $(200 \mathrm{ml})$ with an appropriate dilution was added to $200 \mathrm{ml}$ of distilled water and $1000 \mathrm{ml}$ of $50 \mathrm{mM}$ Tris- $\mathrm{HCl}, \mathrm{pH} 8.0$ containing $10 \mathrm{mM} \mathrm{CaCl}_{2}$ (Sigma). To initiate the reaction, $200 \mathrm{ml}$ of BAPNA ( $2 \mathrm{mg} / \mathrm{mL})$ was added and mixed thoroughly. After incubation for $10 \mathrm{~min}$ at $25^{\circ} \mathrm{C}, 200 \mathrm{ml}$ of $30 \%$ acetic acid (v/v) was added to terminate the reaction. The reaction mixture absorbance was read at $410 \mathrm{~nm}$.

Amylase (E.C. 3.2.1.1) activity was assayed by the dinitrosalicylic acid (DNS, Sigma ${ }^{\circledR}$ ) procedure (Bernfeld, 1955) using $1 \%$ soluble starch (Sigma) as a substrate. Tissue homogenate $(10 \mu \mathrm{l})$ was incubated for $30 \mathrm{~min}$ at $35^{\circ} \mathrm{C}$ with $500 \mu \mathrm{l}$ universal buffer and $40 \mu$ l soluble starch. The reaction was terminated by adding $100 \mu \mathrm{l}$ DNS (D0550, Sigma ${ }^{\circledR}$ ) and heating in boiling water for $10 \mathrm{~min}$. The reducing groups released from starch by amylase action are measured by the reduction of the color reagent, DNS. The boiling water stops amylase activity, catalyzes the reaction of DNS, and reduces groups of starch. The absorbance of the solution was recorded at $540 \mathrm{~nm}$.

Lipase (E.C.3.1.1.3) activity was measured spectrophotometrically (Winkler and Stuckman 1979) with slight modifications. The substrate solution containing 10 $\mathrm{ml}$ of isopropanol (19516, Sigma $\left.^{\circledR}\right)$ and $30 \mathrm{mg}$ of $p$ nitrophenyl palmitate (N2752, Sigma) was mixed with 90 $\mathrm{ml}$ of Tris- $\mathrm{HCl}$ buffer $(50 \mathrm{ml}, \mathrm{pH} 9.0)$, containing $0.4 \%$ Triton-X-100 (X100, Sigma) and $100 \mathrm{mg}$ of gum arabic $\left(G 9752\right.$, Sigma $\left.{ }^{\circledR}\right)$. Freshly prepared substrate solution $(2.4$ $\mathrm{ml}$ ) was incubated at $37^{\circ} \mathrm{C}$ with $25 \mu \mathrm{l}$ of suitably diluted cell-free supernatant for $15 \mathrm{~min}$. After incubation, absorbance was measured at $410 \mathrm{~nm}$ by using a spectrophotometer (Analytikjena-SPECORD 50, Germany) against a control with heat inactivated enzyme.

The hepatic samples used for the determination of CAT, SOD activities and MDA levels. Tissue samples were homogenized in $1 / 5(\mathrm{w} / \mathrm{v})$ ratio of physiological saline solution $(0.8 \% \mathrm{NaCl})$ with a homogenizer and then centrifuged at $13500 \mathrm{rpm}$ for $10 \mathrm{~min}$ in a Sigma 2-16 K centrifuge at $+4^{\circ} \mathrm{C}$. The supernatants were then used for biochemical analyses. Catalase (E.C. 1.11.1.6) activity was determined according to the method of Aebi (1974). Enzymatic decomposition of $\mathrm{H}_{2} \mathrm{O}_{2}$ was directly followed by decrease in absorbance at $240 \mathrm{~nm}$. The difference in absorbance per unit time was used as a measure of CAT activity. The enzyme activity was expressed as unit (U) $\mathrm{mg}$ / protein. Superoxide dismutase (E.C. 1.15.1.1) activity was measured by inhibition of nitroblue tetrazolium (NBT) reduction due to $\mathrm{O}_{2}$ generated by the xanthine/xanthine oxidase system (Sun et al., 1988). One unit of SOD activity was defined as the amount of protein causing $50 \%$ inhibition of NBT reduction rate. Reduction in NBT by superoxide anion to blue formazan was $560 \mathrm{~nm}$. Enzyme activity was given in U/mg protein. MDA levels were measured as an index of LPO, by the thiobarbituric acid reaction according to the methods of Yagi (1998), based on measurement of the absorbance of pink color produced by interaction of TBA with MDA at $530 \mathrm{~nm}$. Values were expressed as nanomole (nmol) per mg protein.

All enzyme activities are expressed as specific activity (U mg /protein). Tissue protein content was determined according to the method developed by Lowry et al. (1951) using bovine serum albumin as standard.

\section{Statistical Analysis}

Data were subjected to a one-way analysis of variance (ANOVA). After identification of differences among groups Duncan's new multiple range tests were used to make multiple comparisons among means. Differences were considered significant at $\mathrm{P}<0.05$. Statistical analyses were performed using SPSS 22.0 for Windows.

\section{Results}

The growth performance parameters and survival rate of rainbow trout fed different levels of dietary inulin for 8 weeks are shown in Table 2. There were significant differences between final weight, weight gain, SGR and FCR of rainbow trout fry $2 \%$ inulin diet and control diet $(\mathrm{P}<0.05)$. Similarly, rainbow trout fry fed supplemented inulin diets ( 1 and $2 \%$ inulin) showed significantly higher survival rate compared to control group $(\mathrm{P}<0.05)$. Additionally, analysis of body composition revealed that crude protein, crude lipid and ash levels were not affected by the experimental dietary treatments $(\mathrm{P}>0.05)$ (Table 3$)$.

Optimum growth was reached on G-1 diet, whereas the control diet (G-0) produced the lowest growth rate. Fish fed with $1 \%$ inulin diets final fish weight, weight gain (\%), daily weight gain increase and specific growth rate increased significantly $(\mathrm{P}<0.05)$ when compared control diet no inulin added G-0 diet. (Table 2). There were significant changes in survival between control and $1 \%$ inulin added diets $(\mathrm{P}<0.05)$. 
Table 2 Growth performance and feed utilization of rainbow trout fed with diets containing different levels of inulin

\begin{tabular}{l|ccc}
\hline \multirow{2}{*}{ Parameters } & \multicolumn{3}{c}{ Diet Groups } \\
\cline { 2 - 4 } & G-0 & G-1 & G-2 \\
\hline Initial weight (g) & $34.02 \pm 0.08^{\mathrm{a}}$ & $34.40 \pm 0.22^{\mathrm{a}}$ & $34.48 \pm 0.26^{\mathrm{a}}$ \\
Final weight (g) & $80.88 \pm 0.33^{\mathrm{a}}$ & $89.22 \pm 0.46^{\mathrm{b}}$ & $82.08 \pm 0.41^{\mathrm{a}}$ \\
BWG (g) & $48.86 \pm 0.25^{\mathrm{a}}$ & $54.80 \pm 0.25^{\mathrm{b}}$ & $47.78 \pm 0.56^{\mathrm{a}}$ \\
DWG (g) & $3.12 \pm 0.01^{\mathrm{a}}$ & $3.65 \pm 0.01^{\mathrm{b}}$ & $3.19 \pm 0.01^{\mathrm{a}}$ \\
PBWG (\%) & $137.73 \pm 0.41^{\mathrm{a}}$ & $159.35 \pm 0.39^{\mathrm{b}}$ & $138.03 \pm 0.46^{\mathrm{a}}$ \\
SGR (\%/day) & $1.44 \pm 0.01^{\mathrm{a}}$ & $1.59 \pm 0.01^{\mathrm{b}}$ & $1.45 \pm 0.02^{\mathrm{a}}$ \\
FCR & $1.13 \pm 0.01^{\mathrm{a}}$ & $1.01 \pm 0.01^{\mathrm{b}}$ & $1.13 \pm 0.01^{\mathrm{a}}$ \\
PER & $1.87 \pm 0.01^{\mathrm{a}}$ & $2.12 \pm 0.01^{\mathrm{b}}$ & $1.91 \pm 0.01^{\mathrm{c}}$ \\
Survival rate (\%) & $86.67 \pm 3.85^{\mathrm{a}}$ & $95.56 \pm 2.22^{\mathrm{b}}$ & $88.89 \pm 2.22^{\mathrm{a}}$ \\
\hline
\end{tabular}

BWG: Body Weight Gain; DWG: Daily Weigh Gain; PBWI: Percent Body Weight Gain; SGR: Specific Growth Rate; FCR: Feed Conversion Ratio; PER: Protein Efficiency Ratio. Data in the same row with different superscripts are significantly different $(\mathrm{P}<0.05)$.

Table 3 Proximate composition of rainbow trout fed with diets containing different levels of inulin

\begin{tabular}{l|ccc}
\hline \multirow{2}{*}{ Parameters } & \multicolumn{3}{c}{ Diet Groups } \\
\cline { 2 - 4 } & G-0 & G-1 & G-2 \\
\hline Moisture & $72.58 \pm 0.33$ & $71.21 \pm 0.41$ & $71.38 \pm 0.30$ \\
Crude protein & $19.57 \pm 0.20$ & $19.80 \pm 0.26$ & $20.43 \pm 0.42$ \\
Crude lipid & $5.40 \pm 0.01$ & $5.30 \pm 0.27$ & $5.25 \pm 0.26$ \\
Ash & $2.27 \pm 0.13$ & $2.06 \pm 0.59$ & $2.71 \pm 0.26$ \\
\hline
\end{tabular}

Data in the same row with different superscripts are significantly different $(\mathrm{P}<0.05)$.

Table 4 Results of for bio-economic analysis for the production of $1 \mathrm{~kg}$ weight rainbow trout fed with inulin supplementation

\begin{tabular}{l|ccc}
\hline \multicolumn{1}{c|}{ Parameters } & G-0 & G-1 & G-2 \\
\hline FCR & $1.13 \pm 0.01^{\mathrm{a}}$ & $1.01 \pm 0.01^{\mathrm{a}}$ & $1.13 \pm 0.01^{\mathrm{a}}$ \\
Feed Cost (US.\$/kg) & 1.36 & 1.44 & 1.52 \\
ECR & $1.54 \pm 0.01^{\mathrm{a}}$ & $1.45 \pm 0.01^{\mathrm{b}}$ & $1.73 \pm 0.01^{\mathrm{c}}$ \\
EPI & $0.10 \pm 0.03^{\mathrm{a}}$ & $0.11 \pm 005^{\mathrm{b}}$ & $0.10 \pm 0.01^{\mathrm{a}}$ \\
\hline
\end{tabular}

*Different letters within a same line denote significantly difference $(\mathrm{P}<0.05)$. Values are expressed \pm SEM of three replicates in each group.

The best FCR was obtained at $1 \%$ inulin (G-1) supplementation. On the other hand, fish fed with $1 \%$ inulin supplementation improved nutrient utilization; moreover, fish fed G-1 diet showed highest PER. Prebiotic inulin supplementation did not significantly affect muscle fish composition (Table 3). The level of dietary inulin supplementation significantly $(\mathrm{P}<0.05)$ affected the ECR and EPI values calculated for the research (Table 4).

After the fish were fed different amounts of inulin supplementation for 60 days, the mean pepsin enzyme activities of treatment group were show any differences (Figure 1a.). Fish fed with $1 \%$ inulin supplemented diet were significantly different than control and other inulin added group for trypsin, amylase and lipase activity $(\mathrm{P}<0.05)$ (Figure 1b, c, d).

End of the experiment CAT, SOD activities and MDA level of liver tissue were presented in Figure 2. CAT activity of liver were improved both inulin added group but G-1 group significantly increased $(\mathrm{P}<0.05)$ in $\mathrm{G}-1$ group when compared with control (Figure $2 \mathrm{a}$ ). The increase was $23.54 \%$ in fish fed with $1 \%$ inulin added group. SOD enzyme activity significantly increased $26.44 \%$ in fish fed the $1 \%$ inulin supplemented diet compared with control group (Figure 2b). MDA level of liver tissue was decreased in both inulin added group compared with control group (Figure 2c). MDA level of liver was significantly decreased in $25.06 \%$ (G-1) and $10.95 \%$ (G-2) respectively, inulin added groups $(\mathrm{P}<0.05)$.

\section{Discussion}

The results of the present study indicate that trout fed with $1 \%$ inulin best growth and feed efficiency responses. Thus, the mean BW gain of fish fed the diets containing inulin $(10 \mathrm{~g} / \mathrm{kg})$ was 5.94 higher than that for fish fed the control diet. The improved growth observed in the present study was parallel to one reported for African catfish, $C$. gariepinus (Mahious and Ollevier 2005), Turbot, $P$. maxima larvae (Mahious et al., 2006), hybrid tilapia, Oreochromis aureus X O. niloticus (Hui-Yuan et al., (2007), Atlantic salmon, S. salar (Grisdale-Helland et al., 2008), Caspian roach, $R$. rutilus fry (Soleimani et al., 2012), sturgeon ( $A$. stellatus) juvenile (Akrami et al., 2013) and rainbow trout, (O. mykiss) (Ortiz et al., 2013), juvenile carp, Cyprinus carpio (Mousavi et al., 2016). However, the effect of prebiotics on growth performance of aquatic species can be confusing since some studies with fish have not observed positive improvements in growth performance with dietary supplementation of inulin (Reza et al., 2009; Olsen et al., 2001). These negative effects may be attributed to the to the failure of intestinal microbiota to ferment excessive levels of prebiotics and following increase in the intestine which may be harmful to the enterocytes (Olsen et al., 2001). Considerable variation in growth, feed utilization and health benefits with the dietary use of prebiotics and/or probiotics are possibly dependent on fish species, feeding duration and supplement dose as well as the type of pre- and probiotics (Ganguly et al., 2013). 
Pepsin (A)

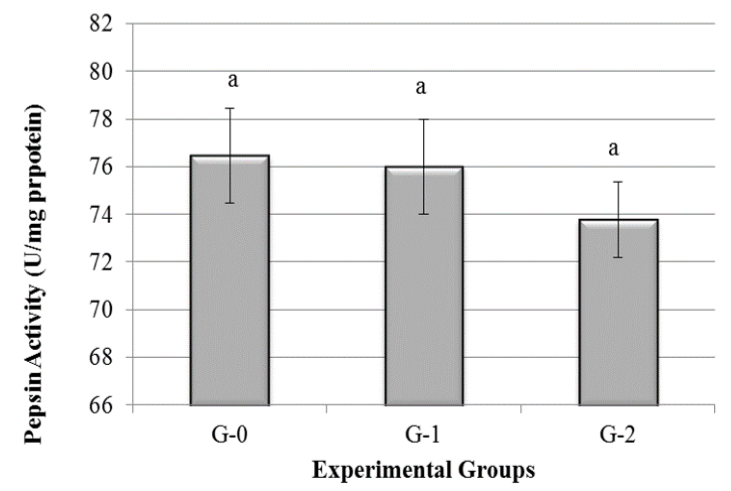

Amylase (C)

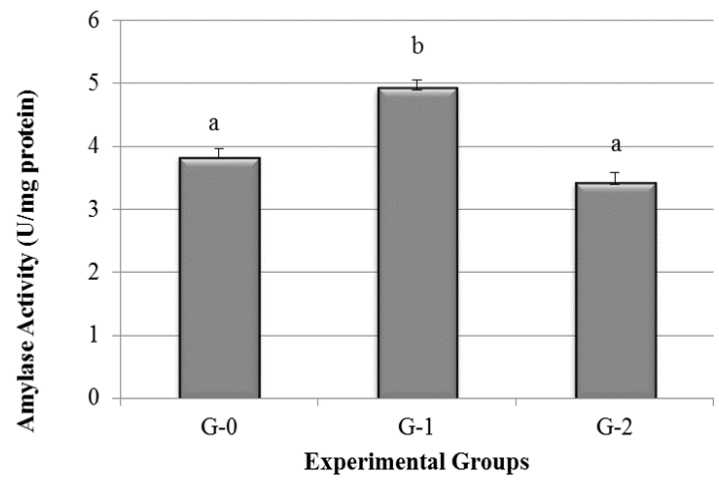

Trypsin (B)

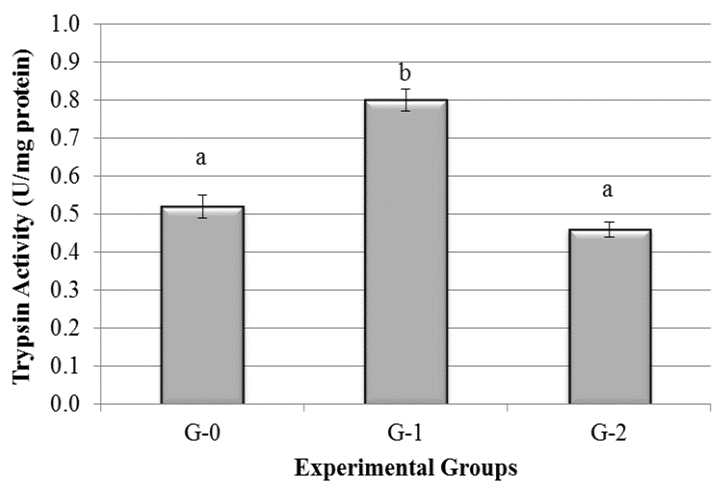

Lipase (D)

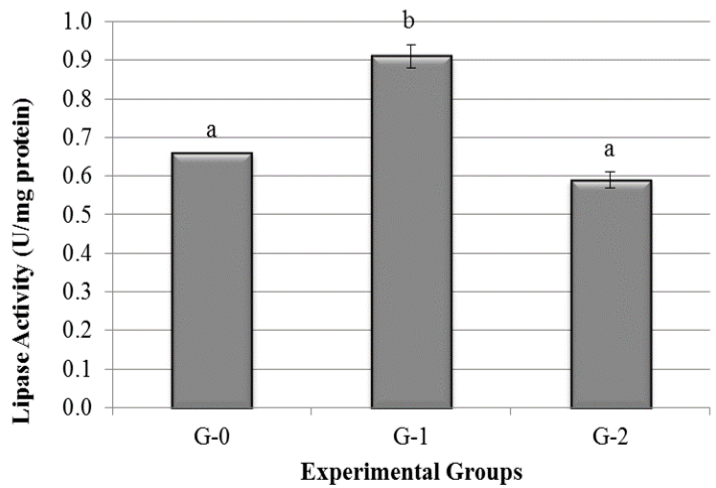

Figure 1 Pepsin (a), Trypsin (b), Amylase (c) and Lipase (d) activity (U mg ${ }^{-1}$ protein) in intestinal tissues of rainbow trout fed different levels of inulin supplementation. Each value represents the mean \pm SEM. $(n=9)$. The different letters indicate significant $(\mathrm{P}<0.05)$ difference between diet groups

In previous studies with inulin; $10 \mathrm{~g} / \mathrm{kg}$ inulin red drum (S. ocellatus) have significantly increased FCR and weight gain (Burr et al.,, 2009); $5 \mathrm{~g} / \mathrm{kg}$ inulin provides better growth in Nile tilapia (O. niloticus) (Ibrahem et al., 2010); In carp (C. carpio) fed with feed containing $5 \mathrm{~g} / \mathrm{kg}$ of inulin, the growth performance of the fish fed with inulin did not significantly differ in feed utilization, but significantly increased the survival rate ( Eshaghzadeh et al., 2015); greater growth and FCR were obtained in trout fed with $5 \mathrm{~g}$ $\mathrm{kg}^{-1}$ of inulin supplemented feed $(\mathrm{P}<0.03)$ (Ortiz et al., 2013); feeds of $0,2.5$, and $5 \mathrm{~g} / \mathrm{kg}$ of inulin added to Nile tilapia (O. niloticus) and increased intestinal villi and goblet cell numbers (Tiengdam, 2015). These all result to parallel to our finding and inulin added groups showed better survival rate when compared with control group but best result showed $1 \%$ inulin added group $(\mathrm{P}<0.05)$.

When a higher amount of fermentable oligosaccharides was used in animal feeding, the increased digesta weight was considered a physiological response of no toxicological significance (WHO, 1987) and often related with some beneficial changes in the gut (lower $\mathrm{pH}$, ammonia reduction and increased amount of short chain fatty acids (SCFA)). In this study, fish fed with higher dose inulin does not showed greater effect for growth but showed better PER amount when compared with control group. Similar to our results Akrami et al (2013), explained that stellate sturgeon (A. stellatus) juvenile roach fed on different levels of FOS had significantly greater PER compared to the control group. One study reported that consumption of $150 \mathrm{~g} / \mathrm{kg}$ inulin on caused damage to the intestines of the Arctic charr (S. alpinus) and the harmful effect of inulin on enterocytes (Olsen et al., 2001). In our study, it was observed that the values of G-2 group were not significantly different than control group but still showed better growth than control group. It is thought that the inulin, which is more than the appropriate dose taken by the fish, may poorly affect the intestinal villas. This contradictory result may be attributable to the dosage (Soleamani et al., 2012), degree of polymerization (Geraylou et al., 2012), different duration of prebiotic administration, life stage and/or different fish species (Soleamani et al., 2012; Akrami et al., 2013, Özlüer-Hunt et al., 2014). Prebiotics increase the solubility and absorption of minerals such as calcium, magnesium and iron ions (Lamprecht and Lipkin, 2003), reducing the intestinal $\mathrm{pH}$ (Breves et al., 2001), and increasing the bioavailability of trace elements (Bongers and van den Heuvel, 2003). In addition, products such as SCFA formed by inulin fermentation in the intestine can be used as an energy source by intestinal cells (Ringø et al., 2010). Furthermore, Bifidobacteria contribute to the production of $\mathrm{B} 1$, riboflavin, $\mathrm{B} 6$ and $\mathrm{K}$ vitamins (Ishibashi and Shimamura, 1993). Moreover, it has a wide-ranging positive health effects (Binaii et al., 2014). Inulin and FOS which motivate in the colon the growth of specific microorganisms, as bifidobacteria and lactobacilli. When we consider that the most important substances for the realization of the digestive function are enzymes, it can be said that by stimulating the enzyme activities of the inulin addition in the correct ratio, the nutrients taken by feed can be digest easily and absorbable molecules, thus better digestion can be achieved. 


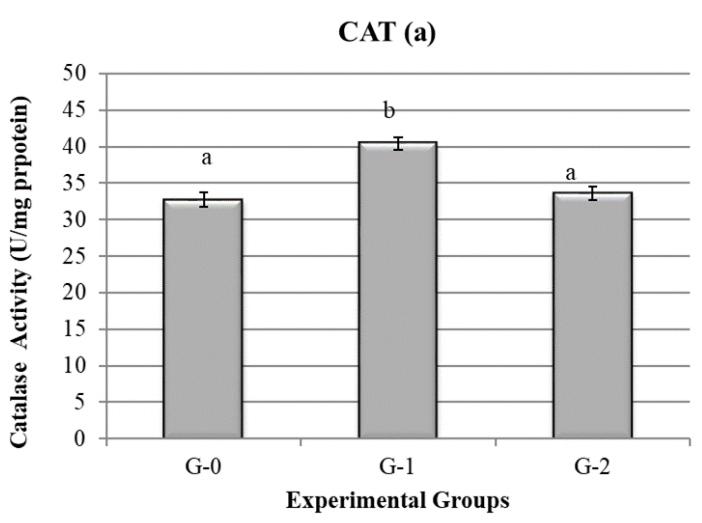

SOD (b)
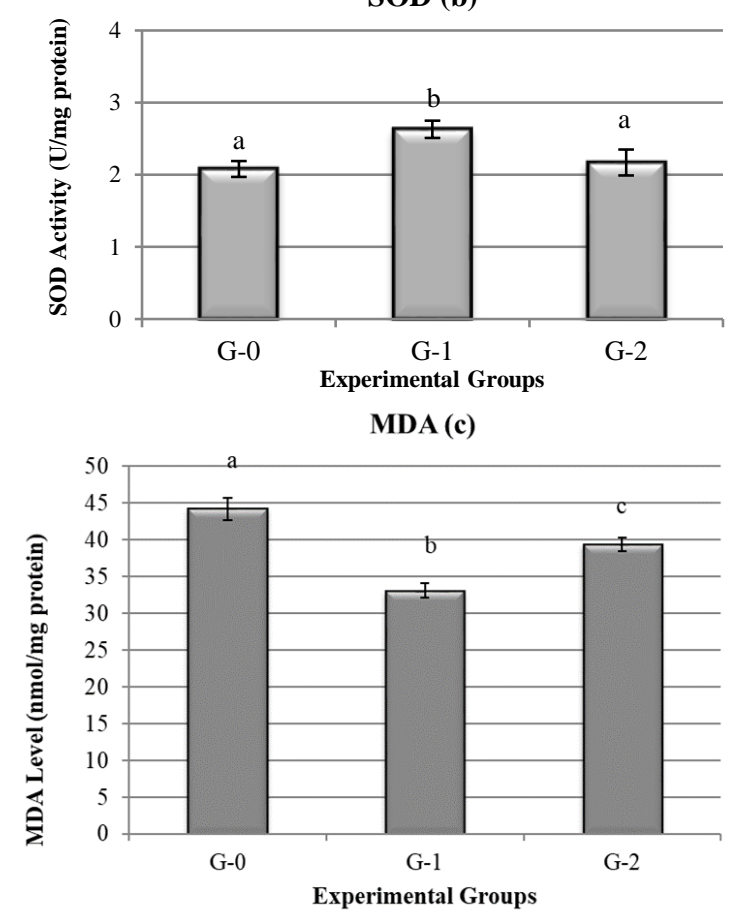

Figure 2 The activities of the antioxidant enzymes (a) catalase (CAT), (b) superoxide dismutase (SOD), and (c) malondialdehyde (MDA) level in liver tissue of rainbow trout fed different levels of inulin supplementation. Each value represents the mean \pm SEM. $(n=9)$. The different letters indicate significant $(\mathrm{P}<0.05)$ difference between dietary treatments.

The results of digestive tract enzyme activity revealed that diets supplemented with inulin does not affect gastric pepsin activity but increased intestinal trypsin, lipase and the amylase enzyme activity fish fed with $1 \%$ inulin added diet significantly. The effects of diets supplemented with inulin on digestive enzymes in rainbow trout are unknown. To our knowledge, this study was the first study to investigate the effects of digestion enzymes of inulin as a prebiotic on rainbow trout. Prebiotics, which are functional dietary supplements, have shown promise for stimulating the immune response, increasing resistance to pathogens, improving growth performance and feed utilization of fish and crustacean species (Ringø et al., 2010). Prebiotics have also increased the efficiency of the digestive tract in many organisms by regulating gut viscosity (Ganguly et al., 2010). Feed-in prebiotic substances increase both the number of intestinal villi and the more standardized shape, thereby expanding the area of nutrient absorption and causing better digestion of nutrients (Dimitroglou et al., 2009; Sweetman et al., 2010). Better absorption and feed intake occurs when the intestinal tract develops and heals. Depending on these reasons, better growth and FCR are attained (Sang and Fotedar 2010). Some prebiotics can be improving growth performance and immune system by balancing the gut microbial community and stimulating the secretion of endogenous digestive enzymes in animals (Wenk, 2003). Prebiotics contribute to digestive function through the production of a number of vitamins and enzymes (Ringø et al., 2007), increasing the efficiency of digestion, leading to an increase in intestinal mucosa (Ramirez and Dixon, 2009). One of the most important purposes of intake inulin with feed is to maximize the digestibility of the food constituents (Sweetman et al., 2010). Soleimani et al (2012), showed that the effects of FOS as a prebiotic on Caspian roach ( $R$. rutilus) fry greater effect digestion enzymes similar to our study. Another study showed, trypsin and chymotrypsin activity was significantly enhanced in C. carpio fed a symbiotic (Enterococcus faecium + FOS) diet but did not show any significant importance amylase and lipase activity (Dehaghani et al., 2015). Inulin has been suggested to have good source for activates the digestion. Some studies on gastrointestinal tract morphology of fish have reported that dietary inulin increase villi density (Tiengtam, 2015) and beneficial bacteria (Mousavi et al., 2016). Digestive enzyme activity may be enhanced by supplemented inulin due to these explanations.

In this present study, CAT and SOD activity was altered fish fed with inulin added diets and increased significantly G-1 inulin group. In addition, MDA level of liver tissue significantly decreased in both inulin added diets indicating a decrease in lipid peroxidation (LPO). The antioxidant enzymes play a crucial role in the inhibition of radical generation and prevention of oxidative damage in teleost (Rudneva, 1997). CAT primarily occurs in peroxisomes where it detoxifies $\mathrm{H}_{2} \mathrm{O}_{2}$ to $\mathrm{O}_{2}$ and water. SOD catalyzes the dismutation of the superoxide anion to molecular oxygen and hydrogen peroxide and is an important component of the antioxidant defense system of the organism. LPO is one of the main processes induced by oxidative stress and is the first step towards causing cellular damage. Many feed supplements, herbs, biostimulating, and immunostimulating compounds stimulate the antioxidant systems of animals. Addition of prebiotic in fish diets stimulated SOD and CAT activity (ReyesBecerril et al., 2008; Dimitroglou et al., 2011; Özlüer Hunt et al., 2011). From the perspective of fish aquaculture, the most positive effects of probiotics and prebiotics reside in their capacity to enhance the fish immune system and antioxidant status. In the present study, feeding $O$. mykiss with inulin diet promoted antioxidant status end of the study. Some research indicated that dietary antioxidants (such as, inulin) could be important for preventing LPO (Stoyavona et al., 2011; Rault-Nania et al., 2008). Similar to our study supplementation of prebiotic in juvenile large yellow croaker, Larimichthys crocea and FOS in triangular bream, Megalobrama terminalis (Zhang et al., 2013) increase the antioxidant capacity of fish. The decreased MDA content usually indicates increased enzymatic antioxidants of the defense system due to the fact that MDA is a direct evidence of the toxic processes caused by 
free radicals (Nogueria et al., 2003). The supplementation of inulin increases the antioxidant capacity of trout but little evidence is available on improved antioxidant capacity by providing inulin in fish, so further studies are needed in future.

The possible effect of prebiotic inulin supplementation on cost production was also calculated end of the study. The lowest ECR and highest EPI values were obtained on fish fed $1 \%$ dietary inulin supplemented rainbow trout. The best FCR was obtained on $1 \%$ inulin supplemented groups thereby significantly lowering final cost of production compared to the control diet. Calculated ECR in trout fed with $1 \%$ supplemented feed (US\$1.45 kg-1) would represent a saving of US\$ $0.09 / \mathrm{kg}(5.85 .3 \%)$ compared to the control diet (US\$ $1.54 / \mathrm{kg}$ ). Between $40-50 \%$ of the variable cost of rainbow trout production is attributed to feed (Vandenberg and Moccia, 1998). Therefore 5.85\% reduction in the feed price per $\mathrm{kg}$ would represent a 2.34 $2.93 \%$ saving in production costs per year.

Nowadays biotechnology developments make a great contribution to the efforts to increase the yields of the breed, which is the most important goal in the aquaculture, by accelerating the development of the species with less feed, increasing the quality of the product together with the quantity of the product obtained from the unit area / volume. Biotechnological products used in animal breeding, such as enzymes, organic acids, probiotics and prebiotics, are both natural, they do not leave residues in tissues and animal products, they do not damage the digestive tract's ecosystem and they also have performance enhancing properties (such as antibiotics and chemotherapeutics) are the most important alternatives because they do not attitude a health hazard. These substances, which are fertility and health-improving benefits in the production of animal products, which are the main protein sources of humans, will be able to provide great benefits to the aquaculture sector in the future by increasing the relevant investigations and revealing their full benefits.

\section{Acknowledgments}

The authors would like to thank Mersin University Research Fund (2015-TP-1060) in Turkey.

\section{References}

Aebi H. 1974. Catalase. In: Bergmayer H.U. (ed) Methods of enzymatic analysis. Academic Press, NewYork, 671-684 pp.

Akrami R, Iri Y, Rostami, HK, Mansour MR. 2013. Effect of dietary supplementation of fructooligosaccharide (FOS) on growth performance, survival, lactobacillus bacterial population and hemato-immunological parameters of stellate sturgeon (Acipenser stellatus) juvenile. Fish and Shellfish Immunology, 35: 1235-1239.

AOAC 1990. Official methods of analysis of the association of official analytical chemists, (Edited by Kenneth Helrich) 15 th ed.

Bailey J, Blankenship L, Cox N. 1991. Effect of fructooligosaccharide on Salmonella colonization of the chicken intestine. Poultry Science, 70: 2433-2438.

Benjakul S, Visessanguan W, Thummaratwasik P. 2000. Isolation and characterization of trypsin inhibitors from some Thai legume seeds. Journal of Food Biochemistry, 24: 107-127.

Bernfeld P. 1955. Amylases, $\alpha$ and $\beta$. Methods in Enzymology, 1: 149-158.
Binaii M, Ghiasi M, Farabi SMV, Pourgholam R, Fazli H, Safari R, Alavi SE, Taghavi MJ, Bankehsaz Z. 2014. Biochemical and hemato-immunological parameters in juvenile beluga (Huso huso) following the diet supplemented with nettle (Urtica dioica). Fish and Shellfish Immunology, 36: 46-51.

Bongers A, van den Heuvel EGHM. 2003. Prebiotics and the bioavailability of minerals and trace elements. Food Reviews International, 19: 397-422.

Breves G, Sztkuti L, Schrder B. 2001. Effects on oligosaccharides on functional parameters of the intestinal tract of growing pigs. Deutsche Tierarztliche Wochenschrifte, 108: 246-248.

Burr G, Gatlin DM, Hume M. 2009. Effects of the prebiotics GroBiotic $^{\circledR}$-A and inulin on the intestinal microbiota of red drum, Sciaenops ocellatus. Journal of World Aquaculture Society, 40(4): 440-449.

Causey JL, Slain JL, Tangled BC, Meyer PD. 1998. Stimulation of human immune system by inulin in vitro. Proc of Danone Conference on Probiotics and Immunity, Bonn, Germany.

Denav S, Stayko Y, Moutafchieva R, Beev G. 2009. Microbial ecology of the gastrointestinal tract of fish and the potential application of probiotics and prebiotics in finfish aquaculture. International Aquatic Research, 1: 1-29.

Dehaghani PG. Baboli MJ. Taghavi AM. Ziaei-Nejad S. Pourfarhadi M. 2015. Effect of synbiotic dietary supplementation on survival, growth performance, and digestive enzyme activities of common carp (Cyprinus carpio) fingerlings. Czech Journal of Animal Science, 60(5): 224-232.

Dimitroglou A, Merrifield DL, Moate R, Davies SJ, Spring P, Sweetman J, Bradley G. 2009. Dietary mannan oligosaccharide supplementation modulates intestinal microbial ecology and improves gut morphology of rainbow trout, Oncorhynchus mykiss (Walbaum). Journal of Animal Science 87(10): 3226-3234.

Dimitroglou A, Merrifield DL, Carnevali O, Picchietti S, Avella M, Daniels C, Guroy D, Davies SJ. 2011. Microbial manipulations to improve fish health and production-a Mediterranean perspective. Fish and Shellfish Immunology, 30(1): 1-16.

Ding X, Li ZJ, Chen YQ, Lin HZ, Yang YY, Yang K. 2004. Effects of probiotics on growth and activities of digestive enzymes of Pennaus vannamei. Journal of Fishery Sciences of China,11(6): 580-584.

Elia AC, Waller WT, Norton STJ. 2002. Biochemical responses of bluegill sunfish (Lepomis macrochirus, Rafinesque) to atrazine induced oxidative stress. Bulletin of Environmental Contamination and Toxicology, 68(6): 809-816.

Erlanger B, Kokowsky N, Cohen W (1961) The preparation and properties of two new chromogenic substrates of trypsin. Archives of Biochemistry and Biophysics, 95:271-278.

Eshaghzadeh H, Hoseinifar SH, Vahabzadeh H, Ringø E. 2015. The effects of dietary inulin on growth performances, survival and digestive enzyme activities of common carp (Cyprinus carpio) fry. Aquaculture Nutrition 21(2): 242-247.

FAO (Food and Agriculture Organization) 2016. The state of world fisheries and aquaculture. Rome.

Flickinger EA, Van Loo J, Fahey Jr C. 2003. Nutritional responses to the presence of inulin and oligofructose in the diets of domesticated animals: a review. Critical Reviews in Food Science and Nutrition, 43(1): 19-60.

Flores LM, Olvera-Novoa MA, Guzman-Mendez BE, LopezMadril W. 2003. Use of bacteria Streptococcus faecium and L. acidophilus, and yeast Saccharomyces cervisiae as growth promotersin Nile tilapia (O. niloticus). Aquaculture, 206: 193-201.

Ganguly S, Paul I, Mukhopadhayay SK. 2010. Application and effectiveness of immunostimulants, probiotics, and prebiotics in aquaculture: a review. The Israeli Journal of AquacultureBamidgeh, 62(3): 130-138. 
Ganguly S, Dora KD, Sarkar S, Chowdhury S. 2013. Supplementation of prebiotics in fish feed: a review. Reviews in Fish Biology Fisheries. 23(2): 195-199.

Geraylou Z, Souffreau C, Rurangwa E, D'Hondt S, Callewaert L, Courtin CM, et al. 2012. Effects of arabinoxylanoligosaccharides (AXOS) on juvenile Siberian sturgeon (Acipenser baerii) performance, immune responses and gastrointestinal microbial community. Fish and Shellfish Immunology, 33(4): 718-724.

Gibson GR, Roberfroid MB. 1995. Dietary modulation of the human colonic microbiota: introducing the concept of prebiotics. Journal of Nutrition 125(6): 1401-1412.

Goodwin TW, Mercer EI. 1983. Fructosans. In:Goodwin TW, MercerEI,(eds) Introduction to plant biochemistry. Oxford: Pergamon Press, 261-264.

Grisdale-Helland B, Helland SJ, Gatlin III DM. 2008. The effect of dietary supplementation with mannanoligosaccharide, fructooligosaccharide or galactooligosaccharide on the growth Atlantic salmon (Salmo salar). Aquaculture, 283:163167.

Hui-Yuan L, Zhigang Z, Rudeaux F, Respondek F. 2007. Effects of dietary short chain fructo-oligosaccharides on intestinal microflora, mortality and growth performance of Oreochromis aureus $x$ O. niloticus. Chinese Journal of Animal Nutrition 19:1-6.

Hoseinifar SH, Mirvaghefi A, Mojazi Amiri B, Rostami HK, Merrifield DL. 2011. The effects of oligofructose on growth performance, survival and autochthonous intestinal microbiota of beluga (Huso huso) juveniles. Aquaculture Nutrition, 17:498-504.

Ibrahem MA, Fathi M, Mesalhy S, El-Aty A. 2010. Effect of dietary supplementation of inulin and vitamin $\mathrm{C}$ on the growth, hematology, innateimmunity and resistance of Nile tilapia (Oreochromis niloticus). Fish and Shellfish Immunology, 29: 241-246.

Ishibashi N, Shimamura S. 1993. Bifidobacteria: Research and development in Japan, Food Technology, June: 126-135.

Lamprecht SA, Lipkin M. 2003. Chemo prevention of colon cancer by calcium, vitamin $\mathrm{D}$ and folate, molecular mechanisms. Nature Reviews Cancer, 3: 601-614

Livingstone DR. 2001. Contaminant-stimulated reactive oxygen species production and oxidative damage in aquatic organisms. Marine Pollution Bulletin, 42: 656-666

Lowry OH, Rosebrough NJ, Farr AL, Randall RJ. 1951. Protein measurement with the folin phenol reagent. Journal of Biological Chemistry, 193: 265-275.

Mahious AS, Ollevier F. 2005. Probiotics and prebiotics in aquaculture: a review. In: The1st regional workshop on techniques for enrichment of live food for use in larviculture. 17-26p. 7-11 March, Urima, Iran.

Mahious AS, Gatesoupe FJ, Hervi M, Metailler R, Ollevier F. 2006. Effect of dietary inulin and oligosaccharides as prebiotics for weaning turbot, Psetta maxima (Linnaeus, C. 1758). Aquaculture International, 14: 219-229.

Martínez-Llorens S, Moñino AV, Tomás A, Moya VJ, Pla M, Jover M. 2007. Soybean meal as a protein source in gilthead sea bream (Sparus aurata L.) diets: effects on growth and nutrient utilization. Aquaculture Research 38: 82-90.

Merrifield DL, Dimitroglou A, Foeyb A, Daviesa SJ, Bakera RTM, Bøgwald J, Castexd M, Ringøca E. 2010. The current status and future focus of probiotic and prebiotic applications for salmonids. Aquaculture, 302: 1-18.

Mousavi E, Mohammadiazarm H, Mousavi SM, Ghatrami ER. 2016. Effects of inulin, savory and onion powders in diet of juveniles carp Cyprinus carpio (Linnaeus 1758) on gut microflora, immune response and blood biochemical parameters. Turkish Journal of Fisheries and Aquatic Sciences, 16: 831-838.

National Research Council (NRC). 1993. Nutrient requirements of fish. National Academy Press, Washington DC.
Nogueira CW, Quinhones EB, Jung EAC, Zeni G, Rocha JBT. 2003. Anti-inflammatory and antinociceptive activity of biphenyl diselenide. Inflammation Research, 52: 56-63.

Olsen RE, Myklebust, R, Kryvi H, Mayhew TM, Ringø E. 2001. Damaging effect of dietary inulin on intestinal enterocytes in Arctic charr (Salvelinus alpinus). Aquaculture Research, 32: 931-934.

Ortiz LT, Rebolé A, Velasco S, Rodríguez ML, Treviño J, Tejedor JL, Alzueta C. 2013. Effects of inulin and fructooligosaccharides on growth performance, body chemical composition and intestinal microbiota of farmed rainbow trout (Oncorhynchus mykiss). Aquaculture Nutrition, 19: 475-482.

Özlüer Hunt, A, Berköz, M, Özkan F, Yalın S, Erçen Z, Erdoğan E, Gündüz SG. 2011. Effect of mannan oligosaccharide on growth, body composition, and antioxidant enzyme activity of tilapia (Oreochromis niloticus). The Israeli Journal of Aquaculture, 63: 619-627.

Özlüer Hunt A, Özkan Yılmaz F, Engin K, Berköz M, Gündüz, SG, Yalın S, Şahin NÖ. 2014. The effects of fish meal replacement by yeast based nucleotides on growth, body composition and digestive enzyme activity in rainbow trout juveniles (Onchorchyncus mykiss). The Israeli Journal of Aquaculture, 66: 964-974.

Patterson JA, Burkholder KM. 2003. Application of prebiotics and probiotics in poultry production. Poultry Science, 82: 627-631.

Pool-Zobel B,Van Loo J, Rowland I, Roberfroid MB. 2002. Experimental evidence on the potential of prebiotic fructans to reduce the risk of colon cancer. British Journal of Nutrition, 87: 273-281.

Rault-Nania MH, Demougeot C, Gueux E, Berthelot A, Dzimira S, Rayssiguier Y, Rock E, Mazur A. 2008. Inulin supplementation prevents high fructose diet-induced hypertension in rats. Clinical Nutrition, 27: 276-282.

Reyes-Becerril M, Tovar-Ramírez D, Ascencio-Valle F, CiveraCerecedo R, Gracia-López V, Barbosa-Solomieu V. 2008. Effects of dietary live yeast Debaryomyces hansenii on the immune and antioxidant system in juvenile leopard grouper Mycteroperca rosacea exposed to stress. Aquaculture, 280: 39-44.

Reza, A, Abdolmajid H, Abbas M, Abdolmohammad AK. 2009. Effect of dietary prebiotic inulin on growth performance intestinal microflora,body composition and hematological parameters of juvenile beluga, Huso huso (Linnaeus, 1758). Journal of the World Aquaculture Society, 40: 771-779.

Ringø E, Myklebust R, Mayhew TM, Olsen RE. 2007. Bacterial translocation and pathogenesis in the digestive tract of larvae and fry. Aquaculture, 268: 251-264.

Ringø E, Olsen RE, Gifstad TØ, Dalmo RA, Amlund H, Hemre GI, Bakke AM. 2010. Prebiotic in aquaculture, review. Aquaculture Nutrition 16:117-136

Ramirez RF, Dixon BA. 2003. Enzyme production by obligate intestinal anaerobic bacteria isolated from oscars (Astronotus ocellatus), angel fish (Pterophyllum scalare) and southern flounder (Paralichthys lethostigma). Aquaculture, 227(1-4): 417-426.

Roberfroid MB. 2005. Introducing inulin-type fructans. British Journal of Nutrition, 93, Suppl. 1: 13-25.

Rudneva II. 1997. Blood antioxidant system of Black Sea elasmobranchs and teleosts. Comparative Biochemistry and Physiology Part C, 118: 255-260.

Sang HM, Fotedar R. 2010. Prebiotic mannan oligosaccharide diet improves health status of the digestive system of Marron, Cherax tenuimanus (Smith 1912). Journal of Applied Aquaculture, 22(3): 240-250.

Shrimpton JM, Zydlewski JD, McCormick SD. 2001. The stress response of juvenile American shad to handling and confinement is greater during migration in freshwater than in seawater. Transaction of the American Fisheries Society, 130(6): 1203-1210. 
Smiricky-Tjardes M, Grieshop C, Flickinger E, Bauer L, Fahey Jr G. 2003. Dietary galactooligosaccharides affect ileal and total tract nutrient digestibility, ileal and fecal bacterial concentrations, and ileal fermentative characteristics of growing pigs. Journal of Animal Science, 81: 2535-2545.

Smith RR. 1989. Nutritional energetics (Halver JE. ed), in Fish Nutrition, San Diego. 2-28pp.

Soleimani N, Hoseinifar SH, Merrifield DL, Barati M, Hassan Abadi Z. 2012. Dietary supplementation of fructooligosaccharide (FOS) improves the innate immune response, stress resistance, digestive enzyme activities and growth performance of Caspian roach (Rutilus rutilus) fry. Fish and Shellfish Immunology, 32: 316-321.

Stoyanova S, Geuns J, Hideg E, Den Ende WV. 2011. The food additives inulin and stevioside counteract oxidative stress. International Journal of Food Sciences and Nutrition, 62(3): 207-214.

Sun Y, Oberley LW, Ying L. 1988. A simple method for clinical assay of superoxide dismutase Clinical Chemistry, 34: 497 500

Sweetman J, Torrecillas S, Dimitroglou A, Rider S, Davies SJ, Izquierdo MS. 2010. Enhancing the natural defences and barrier protection of aquaculture species. Aquaculture Research, 41: 345-355.

Tiengtam N. 2015. Effects of inulin and Jerusalem artichoke (Helianthus tuberosus) as prebiotic ingredients in the diet of juvenile Nile tilapia (Oreochromis niloticus). Animal Feed Science and Technology, 207: 120-129.

Tzortzis G, Goulas AK, Gee JM, Gibson GR. 2005. A novel galactooligosaccharide mixture increases the bifidobacterial population numbers in a continuous in vitro fermentation system and in the proximal colonic contents of pigs in vivo. The Journal of Nutrition, 135: 1726-31

Vandenberg GW, Moccia RD. 1998. Growth performance and carcass composition of rainbow trout, Oncorhynchus mykiss (Walbaum), fed the $\beta$-agonist ractopamine, Aquaculture Research, 29(7): 469-479.
Verdonk JM, Shim SB, van Leeuwen P, Verstegen MW. 2005. Application of inulin-type fructans in animal feed and pet food. British Journal of Nutrition, 93: 125-138.

Yagi K. 1998. Simple procedure for specific enzyme of lipid hydroperoxides in serum or plasma. Methods in Molecular Biology, 108: 107-110.

Yunxia Q, Jianzhong S, Guoliang WA. 2001. Review of principal bacterial diseases of mari-culture fish. Transactions of Oceanology and Limnology, 2: 78-87.

WHO 1987. Setting the ADI. In: Principles for the safety assessment of food additives and contaminants in foods, Environmental Health Criteria 70. IPCS International Programme on Chemical Safety in Cooperation with the Joint FAO/WHO Expert Committee on Food Additives (JECFA). World Health Organization, Geneva. 75-85pp.

Wenk C. 2003. Growth promoter alternatives after the ban of antibiotics. Pig News and Information, 24, pp. 11N-16N.

Winkler UK, Stuckman M. 1979. Glycogen, hyaluronate, and some other polysaccharides greatly enhance the formation of exo-lipase by Serratia marescens. Journal of Bacteriology, 138: 663-670.

Worthington V. 1993. Worthington Enzyme Manual. Enzymes and Related Biochemicals. Worthington Chemical New Jersey, US. 399 pp.

Zhang CN, Li XF, Xu WN, Jiang GZ, Lu KL, Wang LN, Liu WB. 2013. Combined effects of dietary fructooligosaccharide and Bacillus licheniformis on innate immunity, antioxidant capability and diseaseresistance of triangular bream (Megalobrama terminalis). Fish and Shellfish Immunology, 35: 1380-1386.

Zhou QC, Alejandro Buentello J, Gatlin III DM. 2010. Effects of dietary prebiotics on growth performance, immune response and intestinal morphology of red drum (Sciaenops ocellatus). Aquaculture, 309: 253-257 